
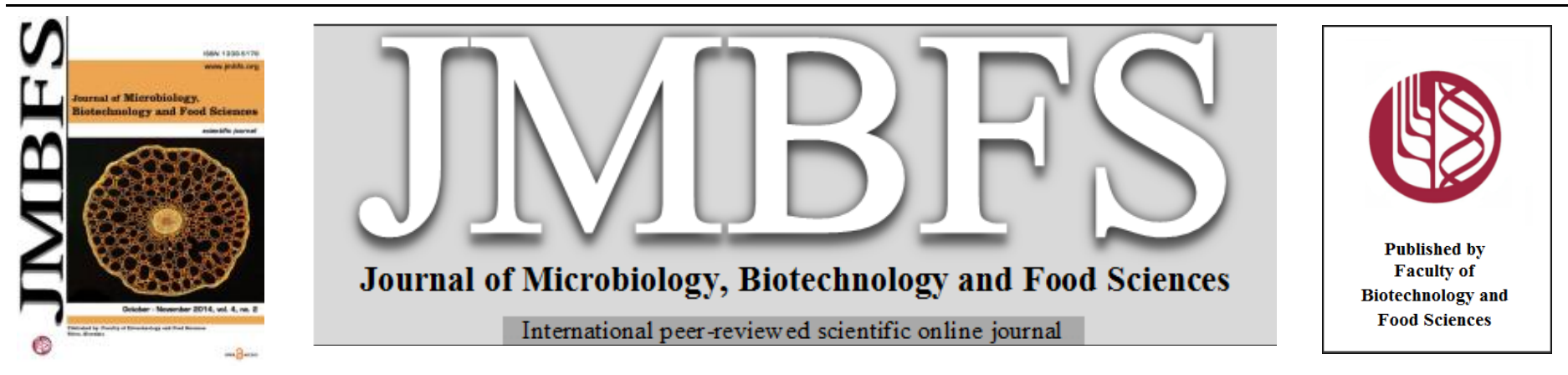

\title{
PHYSICO CHEMICAL CHARACTERIZATION OF A T5-LIKE SALMONELLA PHAGE ФSP-3
}

\section{Jeena Augustine and Sarita G. Bhat*}

Address(es): Dr. Sarita G Bhat, Associate Professor

Department of Biotechnology, Cochin University of Science and Technology, Kalamassery, Cochin-682022, Kerala, India, Tel.: 91-484-2576267,Fax: 91-4842577595.

*Corresponding author: saritagbhat@gmail.com

doi: 10.15414/jmbfs.2014.4.2.102-107

\section{ARTICLE INFO}

Received 26. 5. 2014

Revised 11. 7. 2014

Accepted 18. 8. 2014

Published 1. 10. 2014

Regular article OPEN $\partial_{\text {ACCESS }}$

\begin{abstract}
Antimicrobial resistance is a problem faced by humanity for quite some time now. Search for an intelligent alterative to antibiotics led the scientific community to join hands with an age old foe of pathogenic bacteria - bacteriophages. The present study elaborates the potential of a previously isolated phage with biocontrol capability, to survive and adsorb in various physicochemical environments. ФSP-3, a Salmonella specific lytic phage capable of infecting host in nutrient deprived states with an added advantage of high host specificity and absence of virulence genes as previously reported was chosen for the study. Salmonella Enteritidis was used as host. Basic growth parameters like time taken for phage adsorption, optimal multiplicity of infection (MOI) and one step growth curve, were determined, followed by physicochemical characterization. Various parameters studied include temperature, $\mathrm{pH}$, salinity and presence of sugars and $\mathrm{CaCl}_{2} .25$ minutes of exposure time was required for $100 \%$ adsorption and optimal MOI was calculated as one. The latent period and the rise period was 30 minutes each with a subsequent burst size of 60 phages per bacterium. $\Phi$ SP- 3 could survive upto $70^{\circ} \mathrm{C}$. $1 \mathrm{M} \mathrm{NaCl}$ was optimal for phage viability while $0.25 \mathrm{M}$ favored maximal adsorption. The optimum $\mathrm{pH}$ for $\Phi \mathrm{SP}-3$ viability and adsorption was 8. Among the sugars,Arabinose was most influential in inactivating $\Phi$ SP-3. $100 \%$ adsorption was achieved at both $37^{\circ} \mathrm{C}$ and at $40^{\circ} \mathrm{C} .10 \mathrm{mM}$ of $\mathrm{CaCl}_{2}$ was found to be optimum for $\Phi S P-3$. Thus the present study substantiates the candidature of $\Phi S P-3$ as a sturdy biocontrol agent capable of thriving well in diverse physicochemical environments.
\end{abstract}

Keywords: lytic phages, Salmonella

\section{INTRODUCTION}

Antimicrobial resistance or the ability of microorganisms to withstand treatment with drugs they were once susceptible to, is a significant and multifaceted public health problem. The societal and financial cost of treating antimicrobial-resistant infections place a significant human and economic burden on society, as individuals infected with drug-resistant organisms are more likely to remain in the hospital for a longer period of time and to have a poor prognosis (Lee $\boldsymbol{e t}$ al., 1994). Antimicrobial agents are currently used for three main purposes: (1) to treat infections in human, animals and plants; (2) as prophylactics in human, animals, and plants; and (3) subtherapeutically in food animal as growth promoters and for feed conversion (Angulo et al., 2000). When antibiotic use became the norm in both human and animal medicine, selection pressure increased the bacterial advantage of maintaining and developing new resistance genes that could be shared among bacterial populations (Matthew et al., 2007) The first suggestion that antibiotic use in livestock led to antibiotic-resistant bacteria was in 1951. Starr and Reynolds reported streptomycin resistance in generic intestinal bacteria from turkeys that were fed with antibiotic (Starr and Reynolds, 1951).

Investigations for new alternative anti-microbials, effective against bacterial pathogens have become increasingly relevant for both human and veterinary applications, among which bacteriophage are a potential candidate (Boyle et al., 2007). Phages are natural viral pathogens of bacteria. Salmonella is one amongst many bacterial pathogens against which phages are experimented as therapeutic agents (Kropinski et al., 2006). Numerous bacteriophages specific to Salmonella have been isolated and/or identified as part of host genome sequencing projects. Even though the intimate roles played by phage in Salmonella ecology may complicate their use in biocontrol (McLaughlin et al., 2006), several studies conducted in this direction have given promising results( Boury et al., 2005; Fiorentin et al., 2005 ; Atterbury et al., 2007; Filho et al., 2007). Lytic phages specific for Salmonella have reduced experimental Salmonella contamination in a variety of sources. The first report on this approach was recently published where the authors studied the ability of phages to reduce experimental Salmonella contamination in fresh-cut melons and apples stored at various temperatures (Leverentz et al., 2001). Pao and coworkers too successfully evaluated the potential of bacteriophages to control Salmonella in sprouting seeds in a study, where two isolated and characterized phages where used (Pao et al., 2004). Another recent study showed that applying Felix O1 or its mutant possessing increased in vitro lytic activity against $S$.Typhimurium strain DT104, onto chicken frankfurters experimentally contaminated with the bacterium, reduced its concentration compared to phage-untreated control(Kuhn et al., 2002). Furthermore lytic bacteriophages, applied to chicken skin that had been experimentally contaminated with Salmonella or Campylobacter reduced the pathogen numbers (Goode et al., 2003). A combinatorial approach of bacteriophages and their lysins, together with natural antimicrobial substances has also been employed as evidenced from recent publications, where a combination of Enterobacter asburiae JX1, an organism with antagonistic activity against Salmonella and a Salmonella-specific phage cocktail was shown to be effective against Salmonella associated with tomatoes (Jianxiong $\boldsymbol{e t}$ al., 2009), sprouting mung beans and alfalfa seeds (Ye et al., 2010).

As any phage intended for therapeutic application should by thoroughly studied, the aim of the present study is to characterize a Salmonella specific lytic bacteriophage $\Phi \mathrm{SP}-3$ to ensure its sturdiness. Growth kinetics parameters like adsorption time, optimal MOI, latent period, rise period and the burst size is also intended for study. Latent period is the time elapsed between the moment the host culture is infected with phage to the moment the first bacterial cells are lysed. The rise period is the time span starting from the end of latent period until all phages are extra cellular. Burst size is the average number of progeny phage particles produced per infected bacterium. Knowledge about these parameters will help in understanding the production and release of phage progeny after a subset of time post infection (Choi et al., 2010) which will in turn help in large scale production of phages for further studies. 


\section{MATERIAL AND METHODS}

\section{Salmonella host culture}

Salmonella Enteritidis 9, 12: g, m:- previously isolated and purified in the laboratory and designated as S 49 was used for the present study (Augustine $\boldsymbol{e}$ al., 2013a). Salmonella was isolated following the guidelines of Bacteriological analytical manual, American food and drug administration. Briefly, samples were incubated in lactose broth at $37^{\circ} \mathrm{C}$ for 24 hours for pre enrichment followed by selective enrichment in Rappaport-Vassiliadis and tetrathionate broth at $42^{\circ} \mathrm{C}$ for 24 hours. A loopful of enriched sample was then streaked on to xylose lysine desoxycholate and Hekteon enteric agar. Typical colonies on selective plates were screened based on key biochemical reactions for Salmonella.The 16S rRNA gene sequence analysis of S49 by BLAST showed maximum sequence similarity with Salmonella enterica subsp. Enterica and the sequence was submitted to GenBank (Accession Number: S49 : HQ268500).

\section{Bacteriophage isolation}

Bacteriophage previously isolated from intestinal content of broiler chicken, purified and partially characterized in the laboratory and designated as TSP-3 (Augustine et al., 2013b) were used for the present study. For phage isolation the intestinal contents was homogenized in sterile physiological saline, centrifuged at $4000 \mathrm{~g}$ for 10 minutes at $4^{\circ} \mathrm{C}$, filtered through $0.22 \mu$ membrane filter to make them bacteria- free and the filtrate was screened. The presence of phages in the filtrate was confirmed by double agar overlay method(Adams, 1959). The logarithmic phase cells $(1 \mathrm{~mL})$ of the host bacterial strains in nutrient broth were mixed with $1 \mathrm{~mL}$ of the serially diluted lysate and were incubated at $37^{\circ} \mathrm{C}$ in a water bath for 1 hour. After incubation, $3 \mathrm{~mL}$ of sterile soft agar (nutrient broth containing $0.8 \%$ agarose) was added to this, mixed well and was immediately overlaid on nutrient agar plates. The plates were incubated for 16 hours at $37^{\circ} \mathrm{C}$ Phage-free cultures (containing only bacterial host) and host-free cultures (containing only phage) were used as controls. A sample was scored positive for phages when plaques were observed on the bacterial lawn in the plates. ФSP-3 is a T5 like phage (Accession Number JQ638926) and was unique as it was capable of infecting its host under nutrient-deprived states (Augustine et al., 2013b).

\section{Optimal multiplicity of infection}

MOI is the ratio of phage particles to host bacteria. It is calculated by dividing the number of phage added (volume in $\mathrm{mL} x$ plaque forming units $(\mathrm{PFU}) / \mathrm{mL}$ ) by the number of bacteria added (volume in $\mathrm{mL} x$ colony forming units/mL). Optima MOI was determined according to Lu et al. (2003). Briefly, bacteria were infected at different MOI $(0.01,0.1,0.5,1,5$ and $10 \mathrm{PFU} / \mathrm{mL})$ and were incubated at $37{ }^{\circ} \mathrm{C}$ for one hour. At the end of the incubation period, the mixture was centrifuged at $8000 \mathrm{~g}$ for 10 minutes and supernatant was passed through $0.22 \mu \mathrm{m}$ membrane filter. The lysate was then assayed to determine the phage titre employing the double agar overlay method. All platings were done in triplicates. MOI giving maximum yield was considered as optimal MOI.

\section{Phage adsorption}

The first step in the growth of bacteriophage is its attachment to susceptible bacteria. This process is called adsorption. The adsorption studies were carried out as per Lu et al. (2003). Briefly, log phase culture of host was infected using the optimal MOI of the phage and incubated at $37^{\circ} \mathrm{C}$. Aliquots of $5 \mathrm{~mL}$ were sampled at $0,5,10,15,20,25,30,35,40$ and 45 minutes time intervals after infection. All the samples drawn were immediately filtered through $0.22 \mu \mathrm{m}$ membrane filter. The phage titer was determined using double agar overlay method after appropriate dilutions. All plating was done in triplicates and appropriate controls were maintained. The percentage of phage adsorption was calculated as follows: [(control titer - residual titer)/control titer] X 100\% (Durmaz, 1992). The phage titer observed at time zero was considered as the control titer.

\section{One-step growth curve}

One step growth curve experiment was performed according to the protocol of Capra et al. (2006). Mid log phase culture of the host Salmonella (200 mL) was harvested by centrifugation at $9000 \mathrm{~g}$ for 10 minutes and resuspended in $1 / 5$ of the initial volume $(40 \mathrm{~mL})$ of pre -warmed nutrient broth. The phage was added at the optimal MOI, allowed to adsorb for 15 minutes at $37^{\circ} \mathrm{C}$, followed by harvesting of phages by centrifugation at $10000 \mathrm{~g}$ for 5 minutes and resuspension in $200 \mathrm{~mL}$ nutrient broth. This was incubated at $37^{\circ} \mathrm{C}$. Samples were taken at 10 minutes intervals (up to 2 hours) and immediately titered by the double agar overlay method. All platings were done in triplicates. The graph was plotted with $\log$ of PFU against time. The latent period, the rise period and the burst size of the phage were calculated from one step growth curve.

\section{Influence of physical and chemical parameters on phage viability /infectivity} - Temperature, $\mathrm{NaCl}, \mathrm{pH}$ and sugars

The influence of temperature on phage viabilty was studied at temperatures ranging from $50^{\circ} \mathrm{C}$ to $100^{\circ} \mathrm{C}$ following the protocol of $\mathbf{L u}$ et al. (2003). $900 \mu \mathrm{L}$ of sterile distilled water was pre-heated to temperatures ranging from $50^{\circ} \mathrm{C}$ to $100^{\circ} \mathrm{C}$, followed by the addition of $100 \mu \mathrm{L}$ of phage sample $\left(10^{10} \mathrm{PFU} / \mathrm{mL}\right)$ to these pre-heated tubes. The tubes were maintained at these temperatures for varying intervals, i.e., 15 seconds, 30 seconds, 1 minute, 2 minutes and 3 minutes. After incubation these phage containing tubes were immediately placed in ice. Samples were assayed using double agar overlay method In order to study the influence of $\mathrm{NaCl}$ on phage viability, $\mathrm{NaCl}$ solutions of varying molar concentrations such as $0.1 \mathrm{M}, 0.25 \mathrm{M}, 0.5 \mathrm{M}, 0.75 \mathrm{M}, 1 \mathrm{M}, 2 \mathrm{M}$, and $3 \mathrm{M}$ were prepared in deionised water and phages were incubated for 30 minutes at $37^{\circ} \mathrm{C}$ as per Capra et al.(2006). Influence of $\mathrm{pH}$ on phage viability was evaluated by incubating the phages in suitable buffers of different $\mathrm{pH}$, ranging from 2-11 for 30 minutes at $37^{\circ} \mathrm{C}$. After incubation these phage containing tubes were assayed using double agar overlay method. Effect of various sugars like arabinose, dextrose, galactose, fructose, maltose, mannitol, mannose, lactose, rhamnose, ribose and xylose on phage infectivity was also studied following the protocol with minor modifications(Capra et $\boldsymbol{a l}$., 2006). Sugars were added to a final concentration of $500 \mathrm{mM}$ to each phage sample. All samples after incubation were assayed using double agar overlay plate method to determine the number of surviving PFU. The results were compared with control titre in case of effect of sugars and then expressed as a percentage of phage inactivation. All platings were done in triplicates

\section{Influence of physical and chemical parameters on phage adsorption -} Temperature, $\mathrm{NaCl}, \mathrm{pH}$ and Calcium ions

Effect of temperature, $\mathrm{NaCl}$ and $\mathrm{pH}$ on the adsorption of phages on the host Salmonella Enteritidis was determined following the protocol of Capra $\boldsymbol{e t}$ al. (2006). The temperatures range studied include $0^{\circ} \mathrm{C}, 10^{\circ} \mathrm{C}, 20^{\circ} \mathrm{C}, 30^{\circ} \mathrm{C}, 37^{\circ} \mathrm{C}$, $40^{\circ} \mathrm{C}, 45^{\circ} \mathrm{C}$ and $50^{\circ} \mathrm{C}$. Concentrations of $\mathrm{NaCl}$ investigated include $0.1 \mathrm{M}$, $0.25 \mathrm{M}, 0.5 \mathrm{M}, 0.75 \mathrm{M}$ and $1 \mathrm{M}$. Adsorption rate was determined at the $\mathrm{pH}$ ranging from 2-11. For all the experiments exponentially growing host culture (O.D 600 $=1$ ) was centrifuged, resuspended (approximately $10^{8} \mathrm{CFU} / \mathrm{mL}$ ) in nutrient broth, phages were added at optimal MOI and was incubated, at above mentioned appropriate conditions for 30 minutes followed by centrifugation. The influence of calcium ions $(0 \mathrm{mM}, 1 \mathrm{mM}, 10 \mathrm{mM}, 20 \mathrm{mM}$ and $30 \mathrm{mM}$ concentrations $)$ on phage propagation was determined as per (Lu et al., 2003). The protocol involved adding $10 \mathrm{~mL}$ of exponentially growing Salmonella host culture to 100 $\mathrm{mL}$ nutrient broth, and incubation for 3.5 hours at $120 \mathrm{rpm} .10 \mathrm{~mL}$ each of this mid $\log$ phase host culture was added to five, $15 \mathrm{~mL}$ McCartney bottle Appropriate volumes of filter sterilized $1 \mathrm{M} \mathrm{CaCl}_{2}$ solution were added to the host culture to make $0,1,10,20$, and $30 \mathrm{mM}$ concentrations. After the final volume was adjusted to $15 \mathrm{~mL}$ with sterile distilled water, each tube was infected with the phage at optimal MOI. All tubes were incubated at $37^{\circ} \mathrm{C}$ for 2 hours. In all the experiments supernatant obtained after centrifugation was assayed using double agar overlay method for unabsorbed free phages and the counts were compared with control titre. All platings were done in triplicates. The results were expressed in percentages of adsorption.

\section{Effect of optimized physicochemical parameters on phage propagation}

The cumulative effect of all the parameters thus optimized was studied. Phage lysate was added at its optimum MOI to mid log phase host cells grown in nutrient broth (pH adjusted to 8 with $10 \mathrm{mM} \mathrm{CaCl}_{2}$ and optimum $\mathrm{NaCl}$ concentration). The incubation temperature was set at $40^{\circ} \mathrm{C}$. One step growth curve experiment was repeated. Aliquots were sampled at 10 minutes intervals, mixed with mid log phage host cells grown in nutrient broth $(\mathrm{pH}$ adjusted to 8 with $10 \mathrm{mM} \mathrm{CaCl} 2$ and $0.25 \mathrm{M} \mathrm{NaCl}$ ), followed by incubation for 30 minutes and was immediately titered by double agar overlay method. All platings were done in triplicates. Appropriate controls were maintained. The graph was plotted with $\log$ of $\mathrm{PFU} / \mathrm{mL}$ against time. The latent period, the rise period and the burst size of the phage were calculated.

\section{RESULTS}

\section{Optimal multiplicity of infection}

Optimal MOI was found to be one phage particle per bacterium. This MOI resulting in the highest phage titre under standard conditions were used in all subsequent large scale phage production of $\Phi$ SP-3 unless otherwise specified.

\section{Phage adsorption}

The adsorption curve of $\Phi \mathrm{SP}-3$ is as shown in Figure 1. Adsorption nearing $100 \%$ was achieved after 25 minutes of exposure to the host bacteria. 


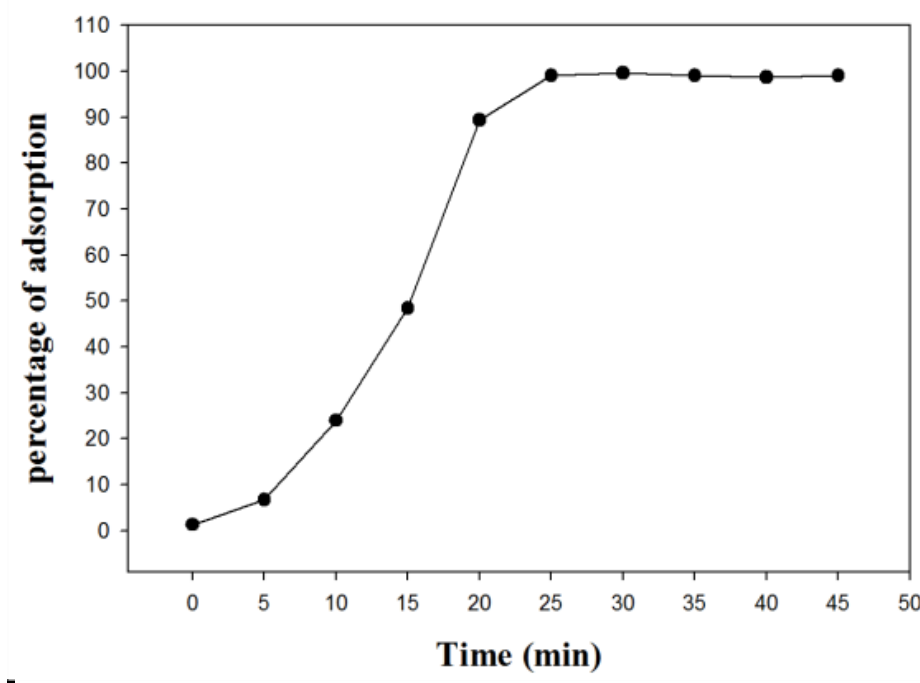

|Figure 1 Adsorption curve of $\Phi S P-3$ at $37^{\circ} \mathrm{C}$

\section{One step growth curve}

The one step growth curve of $\Phi$ SP-3 (Figure 2) clearly showed the latent period and the rise period to be about 30 minutes each. The calculated burst size was 60 phages per bacterium.

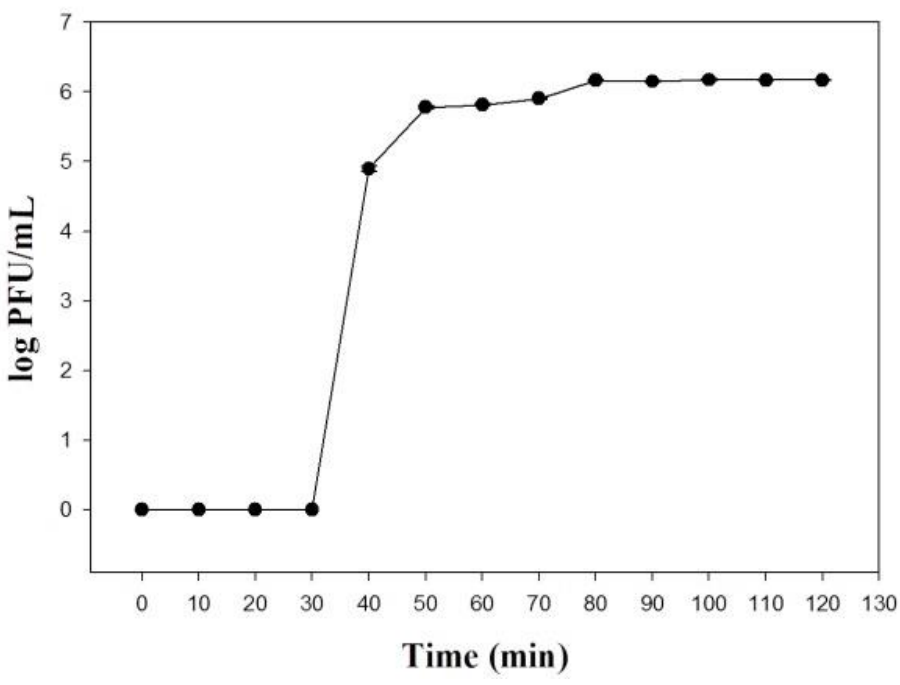

Figure 2 One step growth curve of $\Phi S P-3$ at $37^{\circ} \mathrm{C}$

Influence of physical and chemical parameters on phage viability and adsorption

The influence of temperature variation on viability is as depicted in Figure 3A. Viability was drastically reduced to a few $\mathrm{PFU} / \mathrm{mL}$ at $70^{\circ} \mathrm{C}$, while exposure to temperatures above $70^{\circ} \mathrm{C}$ even for a few seconds, was fatal for phage $\Phi$ SP-3 as there were no survivors. However, considerable survival was noted at $60^{\circ} \mathrm{C}$

The influence of varying concentration of sodium chloride on viability and adsorption is as represented in Figure 3B. $1 \mathrm{M} \mathrm{NaCl}$ was found to be optimal for phage viability. The presence of higher concentrations of $\mathrm{NaCl}$ caused a decline in the viability of $\Phi S P-3.0 .25 \mathrm{M}$ concentrations of $\mathrm{NaCl}$ favored adsorption. Maximum adsorption of $87 \%$ was observed at $0.25 \mathrm{M}$ sodium chloride. Adsorption continued to occur at higher concentration of $\mathrm{NaCl}$ i.e. $0.75 \mathrm{M}$ and $1 \mathrm{M}$ ( 80 and $78 \%$ respectively). The optimum $\mathrm{pH}$ for $\Phi$ SP-3 viability and adsorption was found to be 8 (Figure 3C). It was clear from the figure that $\Phi$ SP-3 could not survive at acidic $\mathrm{pH}$ ranging from 2 to 6 . $\Phi$ SP-3 did not adsorb at $\mathrm{pH}$ $<7$.

The influence of eleven different sugars on viability is depicted in Figure 3D. Arabinose (99\%) followed by xylose (98\%) was found to be the most influential in inactivating $\Phi$ SP-3. Presence of sugars like mannose (90\%), lactose (88\%) and galactose (79\%) also significantly inactivated the phage. Fructose, maltose and dextrose caused $71 \%, 67 \%$ and $66 \%$ phage inactivation respectively. The inhibition capacity exhibited by mannitol $(30 \%)$ and rhamnose $(20 \%)$ was comparatively low. Ribose (5\%) showed the least inhibitory capacity among the sugars studied.

The effect of different temperatures ranging from $0^{\circ} \mathrm{C}$ to $50^{\circ} \mathrm{C}$ on the adsorption of $\Phi S P-3$ is as represented in Figure 3E. Maximum adsorption nearing $100 \%$ was observed at $37^{\circ} \mathrm{C}$ and at $40^{\circ} \mathrm{C}$, while $80 \%$ adsorption was observed at $30^{\circ} \mathrm{C}$. The propagation in the presence of varying concentration of $\mathrm{CaCl}_{2}$ is as depicted in Figure 3F. $10 \mathrm{mM}$ of $\mathrm{CaCl}_{2}$ was found to be optimum for $\Phi S P-3$. The decline in the number of viable viral particles was gradual beyond $10 \mathrm{mM} \mathrm{CaCl}_{2}$

\section{Cumulative effect of optimized parameters on propagation}

ФSP-3 when propagated under optimized parameters resulted in an increase in the phage titre as evidenced from Figure 4. Burst size was raised from 60 to 110 phages per bacterial cell.

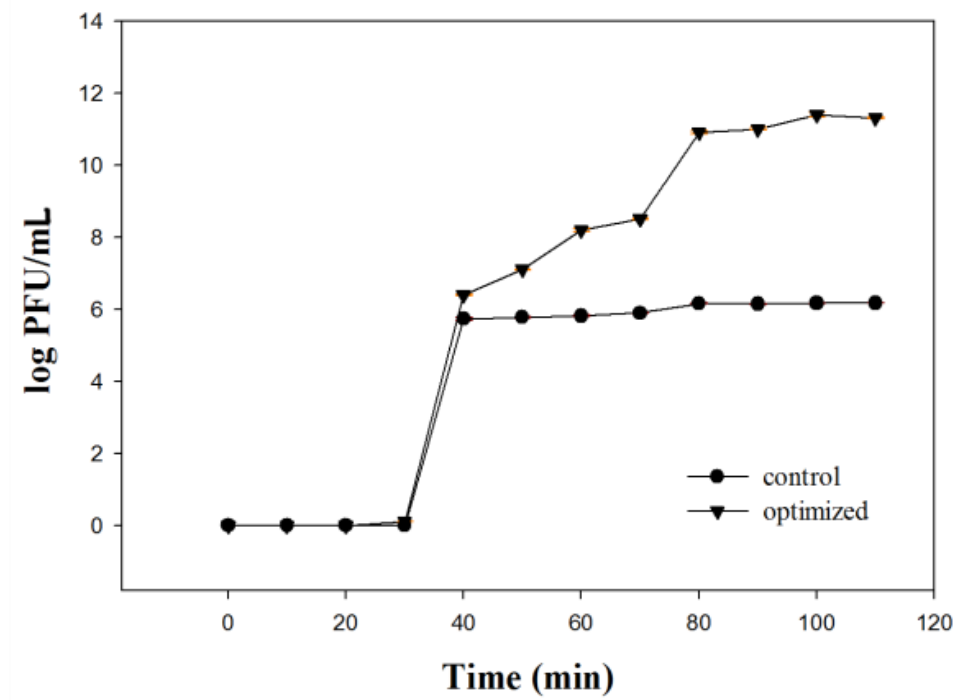

Figure 4 Effect of optimized parameters on propagation of $\Phi S P-3$ at $37^{\circ} \mathrm{C}$ 

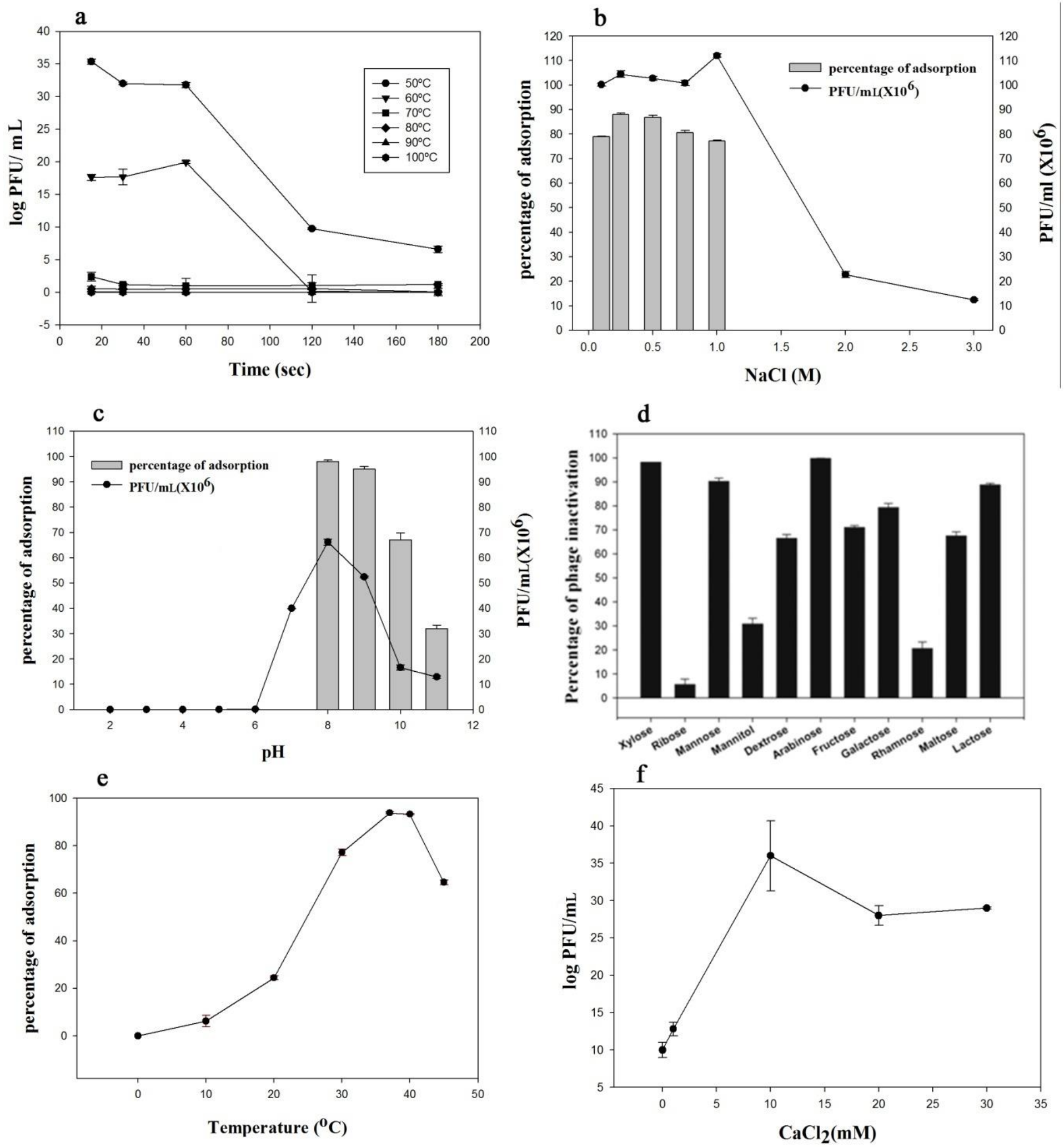

Figure 3 Effect of temperature on viability (Figure 3A), Effect of $\mathrm{NaCl}$ on viability and adsorption (Figure 3B), Effect of pH on viability and adsorption (Figure 3C), Effect of sugars on viability (Figure 3D) Effect of temperature on adsorption (Figure 3E), Effect of $\mathrm{CaCl}_{2}$ on propagation (Figure 3F)

\section{DISCUSSION}

For a fruitful phage- host interaction, several critical factors need to come into play simultaneously. One of the first and important factors is the careful deduction of the optimal MOI. MOI is the ratio of the phage particles to the infected bacteria (Adams, 1959). MOI giving maximum yield per infection is considered as the optimal MOI. Determination of optimal MOI is important as too many phages attaching to a single bacterial cell can cause cell lysis, even before the infection process can yield progeny (lysis from without). On the other hand, if only a few bacteriophages are used for infection, it may be difficult to detect or measure the response being tested (Abedon, 2011). The optimal MOI 
resulting in highest phage titre under standard conditions was used in all subsequent large-scale phage production of TSP-3 using Salmonella host strain S49. Phage adsorption on to the susceptible host is the second significant factor affecting the successful phage- host interaction. Careful determination of the time taken by the phages to adsorb onto to the host cell is of paramount importance, as it may serve in later experiments for accurate characterization of the phage. It took 25 minutes for $100 \%$ adsorption by ФSP-3. The one step growth curve of ФSP-3 using log phase host cells at $37^{\circ} \mathrm{C}$ had a latent period of 30 minutes. The rise period was 30 minutes. The burst size for $\Phi$ SP-3 was 60 phage particles per bacterial cell. The growth kinetics of $\Phi$ SP-3 shared a similar pattern with the well studied Salmonella specific lytic phage, Felix 01 (Kuhn et al., 2002) and with ФSP-1, a lytic phage previously isolated and characterized in the lab (Augustine et al., 2013a). The rise period of Felix 01 is 40 minutes and that of $\Phi S P-1$ is 44 However, the results obtained can only be used/evaluated with caution as the phage multiplication kinetics may vary, depending on the physiological state of the host cell (You et al.,2002) as well as on the environmental conditions which will vary dramatically in natural milieu, compared to the highly controlled lab conditions (Hadas, 1997). However, it is also suggested that the timing of phageinduced host cell lysis may be subject to a host quantity- and host qualitydependent selection. Phages will have a shorter latent period when either host density is high or host quality is good (Abedon, 1989).

Various environmental properties such as temperature and the chemical makeup of the phage-host ecology have a substantial influence (Stent, 1963) not only on the phage viability, but also most importantly on phage adsorption, a very crucia step in phage infection (Capra et al., 2006). Optimal host and growth condition must thus be carefully studied and selected for the production of each bacteriophage candidate for application as biocontrol agents (Sillankorva $\boldsymbol{e t}$ al. 2010). The affect of each parameter and the knowledge about the phage growth dynamics in varying ecological conditions can be exploited during their future intended use as a therapeutic agent. Response of phages on exposure to varying temperatures is considered as a key model for understanding the ability of the organism under question to adapt to novel environments (Johnston and Bennett, 1996). Temperature plays a fundamental role in attachment, penetration, multiplication of phages(Ończyk et al,2011). At lower than optima temperatures, fewer phage genetic material penetrate into bacterial host cells therefore, fewer of them can be involved in the multiplication phase. Higher temperatures can prolong the length of the latent stage (Tey et al., 2009). Moreover, temperature determines the occurrence, viability, and storage of bacteriophages. The influence of temperature variation on ФSP-3 viability revealed that this phage was able to withstand exposure to temperatures as high as $70^{\circ} \mathrm{C}$, without affecting phage viability. The ability to survive higher temperatures is one of the many desirable traits for consideration, especially in its function as biocontrol agent in surface pasteurization of poultry foods where hot water is applied for a short period of time (Augustine et al., 2013a). While studying the effect of temperature on adsorption it was revealed that maximum percentage or nearing $100 \%$ adsorption was at $37^{\circ} \mathrm{C}$ and $40^{\circ} \mathrm{C}$ i.e., at temperatures corresponding to the avian body temperature, which ranges in between $40^{\circ} \mathrm{C}$ and $42^{\circ} \mathrm{C}$. There was no visible adsorption at $0^{\circ} \mathrm{C}$, but it steadily increased as the temperature was raised to $10{ }^{\circ} \mathrm{C}$, an attribute seen as desirable for a biocontrol agent for application in cold storage of food products.

The presence of electrolytes in the phage- bacteria growth medium has a profound effect on the adsorption of phage to host cell. The ionic strength of the solution in which the phage is suspended induces significant effects on its behaviour (Adams, 1959; Furiga et al., 2011). $1 \mathrm{M} \mathrm{NaCl}$ was found to be optimum for viability and $0.25 \mathrm{M} \mathrm{NaCl}$ for adsorption. However ФSP-3 continued to adsorb onto host cells at higher concentrations of $\mathrm{NaCl}$ also.

Certain enzymes produced by phage tail ends have a pivotal role in host cel adsorption ( Murphy, 1957; Richmond, 1959; Eklund and Wyss, 1962). It is conceivable that such a cell-wall lysing enzyme may have a high electrolyte requirement for optimal activity. The enzyme lysozyme located in the phage tail, aids in weakening the bacterial cell wall during the phage adsorption process. It is through this weakened cell wall, that the phage tail fiber injects the bacteriophage DNA into the bacterial cell (Archana, 2007). Finding the optimum $\mathrm{pH}$ for this enzyme activity is important as $\mathrm{pH}$ can interfere with lysozyme or protein coat thereby preventing phage attachment to the receptor sites of the host cell (Leverentz et al., 2001; Leverentz et al., 2004). The optimum $\mathrm{pH}$ range for bacteriophage viability and adsorption is between 5 and 8 (Adams, 1959). ФSP-3 exhibited a similar pattern. $100 \%$ adsorption by $\Phi$ SP-3 was recorded at $\mathrm{pH} 8$ This affinity shown by $\Phi$ SP-3 towards a slightly alkaline environment may be due to their avian caecal origin (Siragusa et $\boldsymbol{a l}$., 2008). This property can be exploited in future in their possible use as a biocontrol agent in the form of feed incorporates to reduce Salmonella load in live poultry.

Capsular polysaccharides of Gram negative bacteria directly involve in phage host interaction (Deveau et al., 2002). In the present study arabinose followed by xylose was most influential in inactivating $\Phi S P-3$. This may be relevant considering that 4-Amino-4-deoxy- arabinose has been previously reported as a constituent in Salmonella LPS preparation (Volkc et al., 1970). It can be inferred that these sugars and/or their analogues may have a key role as phage receptors on the host surface outer membrane, as their presence in the host phage medium during the adsorption stage effectively inhibited the process (Augustine $\boldsymbol{e t}$ al. 2013a). Effect of $\mathrm{CaCl}_{2}$ was also included in the study as numerous work have proved the positive influence of calcium on phage- host interaction. $10 \mathrm{mM}$ of $\mathrm{CaCl}_{2}$ was optimum for $\Phi$ SP-3. Divalent cations are known to play an important role during different stages of bacteriophage infection (Krupovič et al., 2010). In some cases divalent cations are required for phage adsorption (Landry and Zsigray, 1980), in others for viral genome penetration (Watanabe and Takesue, 1972) or another intracellular step during virion development (Nagaraja and Gopinathan, 1980). Mylon et al., (2010) while studying the the growth rate of the phage found that presence of calcium salt positively influenced phage propagation. It was suggested that this resulted from neutralization of the negatively charged moieties on the phage surface by cation binding.

The data collected from the above experiments revealed the physico chemical affinities of $\Phi S P-3$. Propagation under this optimized parameters led to an increase in the titres. The burst size rose from 60 to 110 phages per bacterial cell. An increase in rise period was also observed whereas the latent period remained the same. Both burst size and the phage generation time are controlled by the phage latent period, with greater burst sizes associated with longer latent periods but shorter generation times associated with shorter latent periods (Abedon $\boldsymbol{e t}$ al., 2001). Even though in the present study the latent period remained the same, an overall increase in phage generation time was observed under optimized conditions, which ultimately resulted in an increase in burst size.

\section{CONCLUSION}

The candidature of $\Phi S P-3$ is highly relevant owing to the absence of virulence gene in its genome, high host specificity, and its competence to infect their hos under both nutrient rich and nutrient-deprived as previously reported (Augustine et al., 2013b). In conclusion, the potential of $\Phi S P-3$ as a biocontrol agent was found to be promising owning to its wide range of tolerance towards various physico- chemical parameters. However the studied properties are relevant in the context of control of bacteria under optimal conditions outside a host and so the next step is the check its potential in live animal models like Caenorhabditis elegans.

Acknowledgments: The first author acknowledges the Council for Scientific and Industrial Research (CSIR) India, for the support in the form of Junior and Senior Research Fellowship

\section{REFERENCES}

ABEDON, S.1989. Selection for bacteriophage latent period length by bacteria density: a theoretical examination. Microbial Ecology, 79-88. http://dx.doi.org/10.1007/BF02030117.

ABEDON, S., HERSCHLER, T.D., STOPAR,D.2001. Bacteriophage latentperiod evolution as a response to resource availability. Applied Environmental Microbiology, 67, 4233-4241. http://dx.doi.org/10.1128/AEM.67.9.42334241.200

ABEDON, S.T., KUHL, S.J., BLASDEL, B.G., KUTTER, E.M. 2011. Phage treatment of human infections. Bacteriophage 1, 66-85 http://dx.doi.org/10.4161/bact.1.2.15845.

ANGUlO, F., JOHNSON, K., TAUXE,R., COHEN,M. 2000. Origins and consequences of antimicrobial-resistant nontyphoidal Salmonella: Implications for the use of Fluoroquinolones in food animals. Microbial drug resistance, 6 , 77-83. http://dx.doi.org/10.1089/mdr.2000.6.77.

ADAMS, M.H.1959. Bacteriophages. N. Y. Wiley- Interscience.

ARCHANA, K. 2007. Purification and characterization of Vibriophage isolated from Mangalavanam mangroves. Ph.D Thesis, Department of Biotechnology, Cochin University of Science and Technology.

ATTERBURY, R., VAN, BERGEN, MAP., ORTIZ,F., LOVELL, M.A. HARRIS, J.A., DE BOER, A., WAGENAAR, J.A., ALLEN, V.M.,

AUGUSTINE J., LOUIS, L., VARGHESE, S.M., BHAT, S.G., KISHORE, A. 2013a. Isolation and partial characterization of ФSP-1, a Salmonella specific lytic phage from intestinal content of broiler chicken. Journal of Basic Microbiology, 53, 111-120. http://dx.doi.org/10.1002/jobm.201100319.

AUGUSTINE J., VARGHESE, S.M., BHAT, S.G., 2013b. ФSP-3, a Salmonella specific lytic phage capable of infecting host under nutrient deprived state. Annals of Microbiology, 63, 381-386. http://dx.doi.org/10.1007/s13213-0120485-9

BARROW, P.A. 2007. Bacteriophage therapy to reduce Salmonella colonization of broiler chickens. Applied Environmental Microbiology, 73, 4543-4549. http://dx.doi.org/10.1128/AEM.00049-07.

BOURY, N.M., LEE,N.K.,HARRIS HANK,D.L.2005. Use of bacteriophage Felix 01, HL18 and HL03 to reduce Salmonella enterica Typhimurium burden in mice, Iowa State University Animal Industry Report.

BOYLE, E.C., BISHOP, J.L., GRASSL, G.A., FINLAY, B.B. 2007. Salmonella From pathogenesis to therapeutics. Journal of Bacteriology, 189, 1489-1495. http://dx.doi.org/10.1128/JB.01730-06

CAPRA, M., QUIBERONI, A., REINHEIMER, J. 2006. Phages of Lactobacillus casei/paracasei: response to environmental factors and interaction with collection and commercial strains. Journal of Applied Microbiology, 100, 334-342. 
http://dx.doi.org/doi:10.1111/j.1365-2672.2005.02767.x.

CHOI, C., KUATSJAH, E., WU, E., YUAN, S. 2010. The effect of cell size on the burst size of T4 bacteriophage infections of Escherichia coli B23. Journal of Experimental Microbiology and Immunology, 14,85-91.

DEVEA,U.H., MARIE-R, C., MOINEAU, S. 2002. Effect of exopolysaccharides on phage-host interactions in Lactococcus lactis. Applied Environmental Microbiology ,68, 4364-4369. http://dx.doi.org/10.1128/AEM.68.9.43644369.2002.

DURMAZ, E.1992. A fourth mechanism of bacteriophage resistance in Lactococcus lactis subsp. lactis ME2. MS Thesis. NC State University, Raleigh, NC.

EKLUND, C., WYSS, O. 1962. Enzyme associated with bacteriophage infection. Journal of Bacteriology,84, 1209-1215.

FILHO, A., HIGGINS, J.P., HIGGINS, S.E., GAONA, G., WOLFENDEN, A.D. TELLEZ, G., HARGIS, B.M. 2007. Ability of bacteriophages isolated from different sources to reduce Salmonella enterica serovar Enteritidis in vitro and in vivo. Poultry Science, 86, 1904 -1909. http://dx.doi.org/10.1093/ps/86.9.1904.

FIORENTIN, L., VIEIRA, N.D., BARIONI, JR., W. 2005. Oral treatment with bacteriophages reduces the concentration of Salmonella Enteritidis PT4 in caeca contents of broilers. Avian Pathology, 34, 258-263. http://dx.doi.org/10.1080/01445340500112157.

FURIGA,A.,PIERRE,G.,

GLORIES,M.,AIMAR,P.,ROQUES,C.,CAUSSERAND,C.,BERGE,M.2011.

Effects of ionic strength on bacteriophage $\mathrm{ms} 2$ behavior and their implications for the assessment of virus retention by ultrafiltration membranes. Applied and Environmental

http://dx.doi.org/10.1128/aem.01075-10.

GOODE, D., ALLEN, V.M., BARROW, P.A. 2003. Reduction of experimental Salmonella and Campylobacter contamination of chicken skin by application of lytic bacteriophages.Applied Environmental Microbiology, 69, 5032-5036. http://dx.doi.org/10.1128/AEM.69.8.5032-5036.2003.

HADAS, H., EINAV, M., FISHOV, I., ZARITSKY, A. 1997. Bacteriophage T4 development depends on the physiology of its host Escherichia coli. Microbiology 143, 179 -185. http://dx. doi.org/10.1099/00221287-143-1-179.

JIANXIONG, Y., MAGDALAENA, K., KARI, D., KEITH, W.2009. Evaluation of a biocontrol preparation consisting of Enterobacter asburiae JX1 and a lyticbacteriophage cocktail to suppress the growth of Salmonella Javiana associated with tomatoes. Journal of Food Protection. 72, 2284-2292.

JOHNSTON, I., BENNETT, A.F.1996. Animals and Temperature. Phenotypic and evolutionary adaptation. Cambridge University Press, Cambridge. England. JOŃCZYK,E., KŁAK,M., MIĘDZYBRODZKI,R., GÓRSKI,A. 2011. The influence of external factors on bacteriophages-Review. Folia microbiologica,56,191-200. http://dx.doi.org/doi 10.1007/s12223-011-0039-8. KROPINSKI, A., SULAKVELIDZE, A., KONCZY, P., POPPE, C.2006 Salmonella phages and prophages- genomics and practical aspects. Salmonella, Methods in molecular biology 394, 2007,133-175. http://dx.doi.org/10.1007/978 1-59745-512-1 9 .

KRUPOVIČ,V.C., KRUPOVIČ, M., DAUGELAVIČIUS, R., BAMFORD, D.H 2010. Calcium ion-dependent entry of the membrane-containing bacteriophage PM2 into its Pseudoalteromonas host, Virology, 405(1), 120-128. http://dx.doi.org/10.1016/j.virol.2010.05.021

KUHN, J., SUISSA, M., CHISWELL, D., AZRIEL, A., BERMAN, B., SHAHAR, D., REZNICK, S., SHARF, R., WYSE, J. ,BAR, O.T., COHEN, I., GILES, R., WEISER, I. ,LUBINSKY, M.S.,ULITZUR, S. 2002. A bacteriophage reagent for Salmonella: molecular studies on Felix 01. International Journal of Food Microbiology, 74, 217-227. http://dx.doi.org/10.1016/S0168-1605(01)00682-1.

LANDRY,E.F.,ZSIGRAY,R.M.1980.Effects of calicum on the lytic cycle of Bacillus subtilis phage 41c. Journal of General Virology, 51, 125-135. http://dx.doi.org/10.1099/0022-1317-51-1-125.

LEE, L.A., PUHR, N.D., MALONEY, E.K., BEAN, N.H.,TAUXE, R.V. 1994 Increase in antimicrobial resistant Salmonella infections in the United States, 1989-1990. Journal of Infectionous Diseases, 170, 128-134. http://www.jstor.org/stable//30133485

LEVERENTZ, B., CONWAY, W.S., ALAVIDZE, Z., JANISIEWICZ, W.J., FUCHS, Y., CAMP, M.J., CHIGHLADZE, K.J., SULAKVELIDZE, A.2001 Examination of bacteriophage as a biocontrol method for Salmonella on fresh-cut fruit: A Model Study. Journal of Food Protection, 64, 1116-1121.

LEVERENTZ, B., CONWAY, W.S., JANISIEWICZ, W.J, CAMP, M.J. 2004 Optimizing concentration and timing of phage spray application to reduce Listeria monocytogenes on honeydew melon tissue. Journal of Food Protection, 67, 1682-1686.

LU, Z., BREIDT, JR, F., FLEMING, H.P., ALTERMANN, E., KLAENHAMMER, T.R., 2003. Isolation and characterization of a Lactobacillus plantarum bacteriophage, phiJL-1, from a cucumber fermentation. International Journal of Food Microbiology, 84, 225-235. http://dx.doi.org/10.1016/S0168 1605(03)00111-9.

MATTHEW, A., CISSELL, R., LIAMTHONG, S. 2007. Antibiotic resistance in bacteria associated with food animals: A United States perspective of livestock production. Foodborne Pathogenic Diseases, 4, 115-133 http://dx.doi.org/10.1089/fpd.2006.0066.

MCLAUGHLIN, M.R., BALAA, M.F., SIMS, J., KING, R. 2006. Isolation of Salmonella bacteriophages from swine effluent lagoons. Journal of Environmental Quality, 35, 522-528. http://dx.doi.org/10.2134/jeq2005.0080.

MURPHY, J. 1957. A phage associated enzyme of Bacillus megaterium which destroys the bacterial cell wall. Virology, 4, 563581.http://dx.doi.org/10.1016/0042-6822(57)90086-7.

MYLON, S.E., RINCIOG, C.I., SCHMIDT, N., GUTIERREZ, L.2010. Influence of salt and natural organic matter on the stability of bacteriophage MS2 Langmuir, 26(2), 1035-1042. http://dx. doi:10.1021/la902290t.

NAGARAJA, V., GOPINATHAN, K.P.1980. Requirement for calcium ions in mycobacteriophage I3 DNA injection and propagation. Archives of Microbiology, 124,249-254.

PAO, S., RANDOLPH, S.P., WESTBROOK, E.W., SHEN, H.2004. Use of bacteriophages to control Salmonella in experimentally contaminated sprout seeds. Journal of Food Science 69, 127-129. http://dx.doi.org/10.1111/j.1365 2621.2004.tb10720.x

RICHMOND, M.H.1959. Lytic enzymes of Staphylococcus aureus 524 Biochimica et Biophysica Acta,31, 564-565. http://dx.doi.org/10.1016/00063002(59)90041-1.

SILLANKORVA, S., PLETENEVA, E., SHABUROVA, O., SANTOS, S. CARVALHO, C., AZEREDO, J., KRYLOV, V. 2010. Salmonella Enteritidis bacteriophage candidates for phage therapy of poultry. Journal of Applied Microbiology, 108, 1175-1186. http://dx.doi.org/10.1111/j.1365 2672.2009.04549.x

SIRAGUSA, G., HAAS, G.J., MATTHEWS, P,D., SMITH, R.J., BUHR, R.J. DALE, N.M., WISE, M.G. 2008. Antimicrobial activity of lupulone against Clostridium perfringens in the chicken intestinal tract jejunum and caecum. Journal of Antimicrobial Chemotherapy, 61, 853-858. http://dx.doi.org/10.1093/jac/dkn024.

STARR, M.P., REYNOLDS,D.M. 1951. Streptomycin resistance of coliform bacteria from turkeys fed streptomycin. American Journal of Public Health, 41 1375-1380. http://dx.doi.org/10.2105/AJPH.41.11_Pt_1.1375.

STENT, G. 1963. Molecular Biology of bacterial viruses. WH Freeman. http://dx.doi.org/10.1126/science.143.3604.345

TEY, B.T., OOI, S.T., YONG, K.C., TAN, N. M., LING, T.C., TAN, W.S.2009. Production of fusion $\mathrm{m} 13$ phage bearing the disulphide constrained peptide sequence (C-WSFFSNI-C) that interacts with hepatitis B core antigen. African Journal Biotechnology,8,268-273. http://dx.doi.org/10.5897/AJB2009.000-9043.

VOLKC, W., GALANOSA, C., LUDERITZ, O.1970. The occurrence of 4 Amino-4-deoxy-1-arabinose as a constituent in Salmonella lipopolysaccharide preparations. European Journal of Biochemestry, 17, 223-229. http://dx.doi.org/10.1111/j.1432-1033.1970.tb01157.x.

WATANABE, K., TAKESUE, S. 1972. The requirement for Calcium in infection with Lactobacillus phage. Journal of General Virology, 17, 19-30 http://dx.doi.org/10.1099/0022-1317-17-1-19.

YE, J., KOSTRZYNSKA, M., DUNFIELD, K., WARRINER, K. 2010. Control of Salmonella on sprouting mung bean and alfalfa seeds by using a biocontro preparation based on antagonistic bacteria and lytic bacteriophages. Journal of Food Protection 73, 9-17

YOU, L., SUTHERS, P.F., YIN, J.2002. Effects of Escherichia coli physiology on growth of phage T7 in vivo and in silico. Journal of Bacteriology, 184, 1888 1894. http://dx.doi.org/10.1128/JB.184.7.1888-1894.2002. 